\title{
Glacier balance trends in the Kongsfjorden area, western Spitsbergen, Svalbard, in relation to the climate
}

\author{
Bernard Lefauconnier, Jon Ove Hagen, \\ Jon Børre Ørbæk, Kjetil Melvold \& \\ Elisabeth Isaksson
}

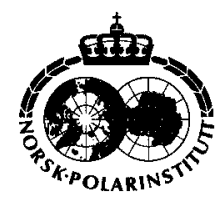

\begin{abstract}
For the last thirty years, the mean net balance of two glaciers, Austre Brøggerbreen and Midre Lovénbreen, has been -0.43 and $-0.34 \mathrm{~m}$ of water equivalent (w.e.). respectively. The mean net balance of Kongsvegen, a tidewater glacier that has been measured since 1987 , is $0.11 \mathrm{~m}$ w.e. The negative balances of the two first glaciers are driven by the increase in atmospheric temperature which occurred at the end of the Little Ice Age at the beginning of the century. The positive balance of Kongsvegen is due to its higher elevation and larger accumulation area. There is no significant trend in the net balances and no increase of the melting has been detected during the last thirty years.

A correlation coefficient of $R=0.83$ has been obtained between the net balance of Lovénbreen and the winter precipitation, together with the summer temperature recorded at the neighbouring station of Ny-Ålesund since 1969. With 14 years of data, the correlation coefficient between the net balance and climatic parameters does not increase consistently by introducing any radiation component, but the coefficient correlation between the summer balance of Austre Brøggerbreen and summer temperature increases from 0.68 to 0.77 when introducing global and long-wave radiation for July and August. Weather conditions and the frequency of their changes influence the balance between global and long-wave radiation and changes in albedo values.
\end{abstract}

B. Lefauconnier, J. B. Ørbakk \& E. Isaksson. Norwegian Polar Institute, Polar Environment Centre, N-9296 Troms $\varnothing$. Norway; J. O. Hagen \& Kjetil Melvold, Dept. of Geography, University of Oslo, Box 1042 Blindern. N-0316 Oslo, Norway.

\section{Introduction}

Arctic glaciers are likely to be particularly sensitive to possible warming through an anthropogenic increase in greenhouse gases. General circulation model (GCM) predictions suggest that such global warming will probably affect the Arctic first. Svalbard, centred around $78^{\circ} 30^{\prime} \mathrm{N}$ and $18^{\circ} \mathrm{E}$, is located within the "North Atlantic anomaly," where temperatures have remained constant or a slightly negative temperature trend has been observed. As the archipelago also lies at the termination of a branch from the North Atlantic current and in the border zone between cold polar and mild maritime air masses, it is strongly affected by the cyclonic tracks originated around the Iceland. Therefore mass balance series recorded in the Kongsfjord area (west Spitsbergen) by the Norwegian Polar Institute since 1967 offer a unique possibility to analyse the recent past behaviour of the glaciers and to watch out for a possible climatic shift. Meteorological records at the neighbouring station of $\mathrm{Ny}$-Alesund provide the opportunity to investigate the relation between glacier balances and climatic parameters.

Most of the Svalbard glaciers are polythermal and about $80-90 \%$ of them are estimated to be of surge type (Lefauconnier \& Hagen 1991; Hagen et al. 1993). Austre Brøggerbreen and Midre Lovénbreen are two small cirque glaciers of 5 and $6 \mathrm{~km}^{2}$ in area, respectively. The thin Brøggerbreen is mainly made of cold ice (Hagen \& Sætrang 1991) and does not possess a real firn area; no water flow is observed in winter. Lovénbreen has a permanent 
firn area and is partly temperate. A permanent water flow builds up a characteristic naled ice at its front in wintertime. Maximum ice flows in the central part of the glaciers do not exceed 4 and $8 \mathrm{~m}$ per year, respectively. Photographs from Hamberg (1895) indicate that Lovénbreen probably surged at the end of the last century.

Kongsvegen, which is $25 \mathrm{~km}$ long with an area of $102 \mathrm{~km}^{2}$, possesses a large firn zone and volume of temperate ice in its higher basin. The surface cold layer reaches the bedrock in the ablation area, and the glacier is partly frozen to the bottom (Hagen \& Sætrang 1991; Björnsson et al. 1996). The ice flow velocity of the Kongsvegen is less than $4 \mathrm{~m}$ per year along the entire basin and the surplus of accumulation is not transported to the ablation area. The glacier seems to be building up to a new surge after the last one which occurred in 1948 (Melvold \& Hagen 1998). The glacier tongue, compressed by the fast flowing Kronebreen, is only a few hundred metres wide and its small tidewater front produces only a very weak calving which is neglected in the balance calculation.

\section{Mass balances}

Methods: The accumulation was calculated from snow depth measurements over the entire basin. Snow density and superimposed ice were measured in snow pits and shallow cores. The ablation was calculated from stake reading along the longitudinal axis of the glaciers. The accumulation was measured in the first half of May, while the ablation was obtained usually in the beginning of September. As the melting period persisted after the autumn measurement, necessary corrections were introduced after new stake measurements which were carried out during the following spring. Results were close to those obtained by using the stratigraphic system of balance determination. As there is some snow fall in May and sometimes at the beginning of June, before the start of the melting period, both winter and summer balances were slightly underevaluated.

Results: The data on mass balances of Austre Brøggerbreen, Midre Lovénbreen and Kongsvegen are given in Table 1; the balances of Midre Lovénbreen are presented in Fig. 1.

Austre Brøggerbreen and Midre Lovénbreen are neighbouring glaciers $5 \mathrm{~km}$ apart with a similar area and north-east exposition. Mean winter accumulation over Brøggerbreen for the period 1967-1997 was $\mathbf{b w}=0.70 \mathrm{~m}$ water equivalent (w.e.), and $\mathrm{bw}=0.74 \mathrm{~m}$ w.e. on Lovénbreen for the period 1968-1997. Standard deviations of 0.15 and $0.17 \mathrm{~m}$ indicate that there were small annual variations. The mean summer balances (bs $=$ -1.13 and $\mathrm{bs}=-1.08 \mathrm{~m}$ w.e., respectively) were 60 and 46\% higher in absolute values than the winter balances, while the standard deviation was almost double of that of the winter balances $(0.28$ and 0.29 against 0.15 and 0.17 , respectively). Negative net balances of $b n=-0.43$ and bn $=-0.34 \mathrm{~m}$ w.e. resulted from ablation which was regularly higher than accumulation. These findings are remarkably similar to the data presented ten years ago by Hagen \& Liestøl (1990). For years with heavy melting, all of Brøggerbreen is an ablation area, with an entirely icy surface. In contrast, Lovénbreen, with a slightly higher basin and more shadows in summer, retains a permanent firn zone.

From 1986 to 1997 , the mean winter, summer and net balances of Kongsvegen were $b w=0.82$. $\mathrm{bs}=-0.70$ and $\mathrm{bn}=0.11 \mathrm{~m}$ w.e., respectively. Although the ELA was about $100 \mathrm{~m}$ higher up than for the two other surveyed glaciers, the net balance was positive due to its higher and larger accumulation area. At the head of the glacier, lower summer temperature combined with snow, led to a reduced ablation. As an example, on a small nunatak $90 \mathrm{~m}$ above the top of the glacier, 45 positive degreedays (PDD) were recorded in 1990, a year for which the ablation was higher than the mean value, while at the station of $\mathrm{Ny}$-Alesund, at sea level and $25 \mathrm{~km}$ to the north-east of the glacier, the annual average was 394 PDD. It is interesting to note that for the three years 1986-89, the net accumulation obtained in accumulation area by the direct glaciological method agrees very well with the results obtained from the detection of the 1986 Chernobyl radioactive layers in shallow cores (Lefauconnier, Hagen et al. 1994).

Balances in 1996-97, an exceptional year: In 1996-97, winter balances were below the mean values by $71 \%$ for Brøggerbreen, $75 \%$ for Lovénbreen and $85 \%$ for Kongsvegen. The low values are linked to a low rate of winter precipitation recorded at Ny-Ålesund (October-May), which was only $66 \%$ of the mean value. The summer balance was equal to the mean value on 
Table 1. Mass balances of Austre Brøggerbreen, Midre Lovénbreen and Kongsvegen. Balances in $\mathrm{m}$ w.e.; bw = winter balance; $\mathrm{bs}=$ summer balance; $\mathrm{bn}=$ net balance; $\mathrm{ELA}=$ equilibrium line altitude (in $\mathrm{m}$ asl); $\mathrm{AAR}=$ Accumulation area ratio.

\begin{tabular}{|c|c|c|c|c|c|c|c|c|c|}
\hline \multirow[b]{2}{*}{ Balance year } & \multicolumn{3}{|c|}{ Austre Brøggerbreen } & \multicolumn{3}{|c|}{ Midre Lovénbreen } & \multicolumn{3}{|c|}{ Kongsvegen } \\
\hline & bw & bs & bn & bw & bs & bn & bw & bs & bn \\
\hline $1966 / 67$ & 0.77 & -1.42 & -0.65 & & & & & & \\
\hline $1967 / 68$ & 0.57 & -0.67 & -0.10 & 0.48 & -0.51 & -0.03 & & & \\
\hline $1968 / 69$ & 0.40 & -1.33 & -0.93 & 0.41 & -1.25 & -0.84 & & & \\
\hline $1969 / 70$ & 0.37 & -0.91 & -0.54 & 0.36 & -0.89 & -0.53 & & & \\
\hline $1970 / 71$ & 0.65 & -1.23 & -0.58 & 0.70 & -1.16 & -0.46 & & & \\
\hline $1971 / 72$ & 0.95 & -1.26 & -0.31 & 0.98 & -1.20 & -0.22 & & & \\
\hline $1972 / 73$ & 0.74 & -0.82 & -0.08 & 0.82 & -0.84 & -0.02 & & & \\
\hline $1937 / 74$ & 0.75 & -1.67 & -0.92 & 0.70 & -1.59 & -0.89 & & & \\
\hline $1974 / 75$ & 0.78 & -1.09 & -0.31 & 0.83 & -1.04 & -0.21 & & & \\
\hline $1975 / 76$ & 0.72 & -1.17 & -0.45 & 0.75 & -1.10 & -0.35 & & & \\
\hline $1976 / 77$ & 0.76 & -0.87 & -0.11 & 0.80 & -0.84 & -0.04 & & & \\
\hline $1977 / 78$ & 0.75 & -1.31 & -0.56 & 0.81 & -1.29 & -0.48 & & & \\
\hline $1978 / 79$ & 0.77 & -1.48 & -0.71 & 0.80 & -1.46 & -0.66 & & & \\
\hline $1979 / 80$ & 0.75 & -1.27 & -0.52 & 0.83 & -1.26 & -0.43 & & & \\
\hline $1980 / 81$ & 0.46 & -1.01 & -0.55 & 0.51 & -0.97 & -0.46 & & & \\
\hline $1981 / 82$ & 0.64 & -0.68 & -0.04 & 0.66 & -0.64 & 0.02 & & & \\
\hline $1982 / 83$ & 0.70 & -0.97 & -0.27 & 0.75 & -0.92 & -0.17 & & & \\
\hline $1983 / 84$ & 0.69 & -1.42 & -0.73 & 0.74 & -1.42 & -0.68 & & & \\
\hline $1984 / 85$ & 0.93 & -1.48 & -0.55 & 0.98 & -1.46 & -0.48 & & & \\
\hline $1985 / 86$ & 0.98 & -1.30 & -0.32 & 1.06 & -1.27 & -0.21 & & & \\
\hline $1986 / 87$ & 0.82 & -0.60 & -0.22 & 0.82 & -0.58 & 0.24 & 0.92 & -0.39 & 0.54 \\
\hline $1987 / 88$ & 0.61 & -1.13 & -0.52 & 0.56 & -1.05 & -0.49 & 0.74 & -0.74 & 0.00 \\
\hline $1988 / 89$ & 0.56 & -1.01 & -0.45 & 0.63 & -0.87 & -0.24 & 0.55 & -0.70 & -0.15 \\
\hline $1989 / 90$ & 0.75 & -1.41 & -0.66 & 0.87 & -1.38 & -0.51 & 0.81 & -1.12 & -0.31 \\
\hline $1990 / 91$ & 0.92 & -0.79 & 0.13 & 0.98 & -0.88 & 0.10 & 0.89 & -0.47 & 0.43 \\
\hline $1991 / 92$ & 0.69 & -0.89 & -0.10 & 0.84 & -0.98 & -0.14 & 0.90 & -0.56 & 0.34 \\
\hline $1992 / 93$ & 0.54 & -1.57 & -1.03 & 0.68 & -1.56 & -0.88 & 0.75 & -1.07 & -0.32 \\
\hline $1993 / 94$ & 0.79 & -0.95 & -0.16 & 0.87 & -0.99 & 0.12 & 1.01 & -0.52 & 0.49 \\
\hline $1994 / 95$ & 0.56 & -1.34 & -0.78 & 0.52 & -1.31 & -0.79 & 0.53 & -0.80 & -0.27 \\
\hline $1995 / 96$ & 0.78 & -0.95 & -0.17 & 0.80 & -0.78 & 0.02 & 1.16 & -0.77 & 0.39 \\
\hline $1995 / 97$ & 0.50 & -1.12 & -0.71 & 0.56 & -0.98 & -0.43 & 0.70 & -0.60 & 0.10 \\
\hline Mean value & 0.70 & -1.13 & -0.43 & 0.74 & -1.08 & -0.34 & 0.82 & -0.70 & 0.11 \\
\hline St. deviation & 0.15 & 0.28 & -0.31 & 0.17 & 0.29 & 0.31 & 0.19 & 0.23 & 0.36 \\
\hline Mean ELA & & & 417 & & & 396 & & & 505 \\
\hline St. deviation & & & 107 & & & 97 & & & 78 \\
\hline AAR & & & 0.25 & & & 0.36 & & & 0.59 \\
\hline
\end{tabular}

Brøggerbreen and slightly lower on Lovénbreen (91\%) and Kongsvegen (85\%).

During the ten years with results from the three glaciers (1987-1997), the net balances of the three glaciers followed an identical trend of annual variation. That was not the case for the year 1996-97. Brøggerbreen showed a net balance substantially lower than the average $(-0.71$ against $-0.43 \mathrm{~m}$ w.e.), Lovénbreen slightly below the average $(-0.43$ against $-0.34 \mathrm{~m}$ w.e. $)$ and Kongsvegen a net balance equal to the mean value $(0.11 \mathrm{~m}$ w.e). It is interesting to note that the accumulation area ratios (AAR) were, respectively, $7 \%, 36 \%$ and $45 \%$. Surprisingly, the last value corresponded to a net balance which was clearly positive, although in Svalbard a zero balance usually corresponds to an AAR of 0.60 or 0.65 . Meteorological records (data from the Norwegian Meteorological Institute) indicate that, if the number of PDD was close to the average, the precipitation in summer was $36 \%$ above normal and recorded during 39 days in July and August. Summer 1997 was characterized by heavy cloud cover and snowfall at the top of the glaciers. For the first time, the summer accumulation at the top of Kongsvegen was higher than the ablation.

\section{Correlation between glacier balances and meteorological data}

A multivariate analysis between glaciological and 
(m w.e.)

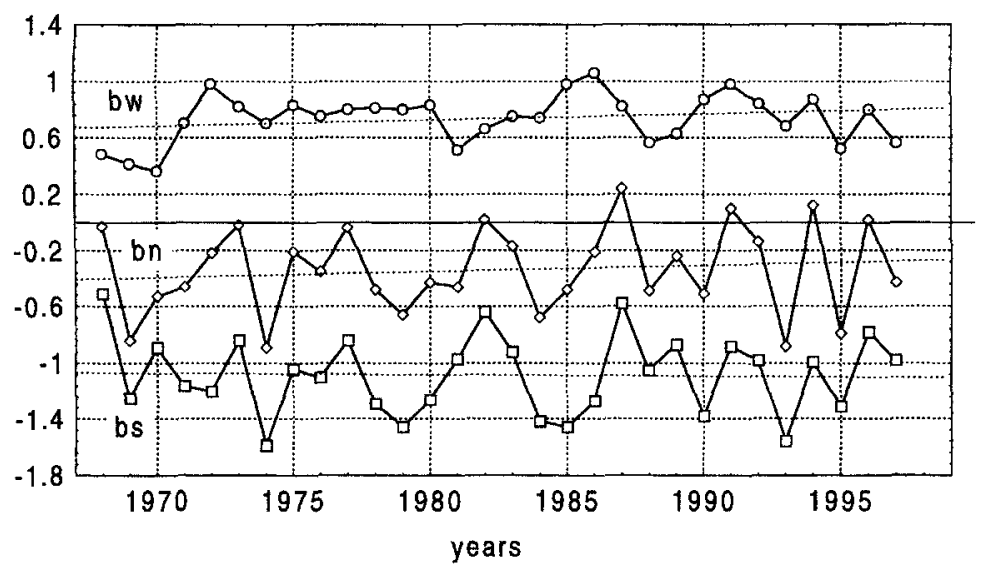

Fig. 1. Midre Lovénbreen balances given in $\mathrm{m}$ water equivalent ( $m$ w.e.). $\mathrm{Bw}=$ winter balance; $\mathrm{bs}=$ summer balance; $\mathrm{bn}=$ net balance. meteorological parameters such as developed by Martin (1977) has already been conducted by using balance data for Brøggerbreen (Lefauconnier \& Hagen 1990). Here we present the same type of analysis with a further ten years of data.

Balances, winter precipitation and summer temperature: Meteorological records at $\mathrm{Ny}$-Ålesund started in 1969. The station is located $1.5 \mathrm{~km}$ from Austre Brøggerbreen and $5 \mathrm{~km}$ from Midre Lovénbreen. Winter precipitation $(\mathrm{Pw})$ is expressed in $\mathrm{m}$ w.e. and summer temperature in PDD. The parameters used are presented in Table 2 , the results in Table 3.

For the complete period of measurements (see, e.g. Fig. 1) there is no trend in the net balance of Brøggerbreen and a slightly positive one for Lovénbreen (from bn $=-0.40$ to $\mathrm{bn}=-0.28 \mathrm{~m}$ w.e.) due to a slightly positive trend (20\%) in the winter balance. Moving the origins and/or the ends of the series by one or two years changes the trend, which sometimes becomes zero but never negative. During the period with climatic record (1969-1997), winter precipitation (at $7 \mathrm{~m}$ asl) increased from 229 to $300 \mathrm{~mm}$ in water equivalent and the number of PDD decreased from 405 to 383 . These changes are too weak to lead any conclusion. For the two glaciers, a zero net balance would be obtained if the temperature were lowered by about $0.7^{\circ} \mathrm{C}$ or if the winter precipitation were increased by ca. $35-45 \%$ (i.e. $10-13 \mathrm{~cm}$ w.e.). A summer temperature rise of one degree would induce a net balance around bn $=-0.7 \mathrm{~m} \mathrm{a}^{-1}$ w.e.

The multiple correlation coefficient between the
Lovénbreen net balance and winter precipitation plus summer temperature is $R=0.81$ when using all PDD from July to October. The coefficient is $\mathrm{R}=0.85$ when introducing separately the PDD of the months of July, August, and September together with October. This correlation explains $72 \%$ of the variance.

\section{Radiation}

Radiation has been recorded by the Norwegian Polar Institute in Ny-Ålesund since 1974, although data from 1985 and 1986 are missing and there are important lacunae in the data for some other years. The 1974-75 and 1981-1992 series have been published (Vijne 1976, 1977a, b, 1978, 1979, 1980; Hisdal et al. 1992; Hisdal \& Finnekåsa 1996). A test using only eight years of data was made (Lefauconnier \& Hagen 1990), yielding an exceptionally good result: the multiple correlation coefficient between mass balance and winter precipitation plus summer temperature and longwave radiation received during the month of July and August was $\mathrm{R}=0.98(\mathrm{R}=0.88$ without the radiation). In this work we use all available data to: a) detect in a 14 year series a possible confirmation of a relationship between glacier balances and radiation components; b) possibly discriminate between the roles played by global versus longwave radiation; and c) provide an orientation for future research. As the radiation was recorded over a tundra field and not over a glacier surface, only downward radiation records are used and not the 
Table 2. Values of the main climatic parameters used in the calculations and mentioned in the text. Pw $=$ winter precipitation in $\mathrm{m}$ of water; dd-07, dd-08, dd-09-10 = positive degree-days in July, August, and September together with October; LW-07, LW$08=$ downward long-wave radiation recorded at the station of Ny-Ålesund in July and August; SW-07, SW-08 = global radiation in July and August in $10^{-2} \mathrm{MJ} \mathrm{m}^{-2}$.

\begin{tabular}{|c|c|c|c|c|c|c|c|c|}
\hline Balance year & $P w$ & $d d .07$ & $d d-08$ & $d d 08-09$ & $L W-07$ & $L W-08$ & $S W-07$ & $S W-08$ \\
\hline \multicolumn{9}{|l|}{$1966 / 67$} \\
\hline \multicolumn{9}{|l|}{$1967 / 68$} \\
\hline $1968 / 69$ & & 169 & 111 & 72 & & & & \\
\hline $1969 / 70$ & 0.17 & 144 & 122 & 52 & & & & \\
\hline $1970 / 71$ & 0.16 & 184 & 121 & 41 & & & & \\
\hline $1971 / 72$ & 0.28 & 154 & 146 & 60 & & & & \\
\hline $1972 / 73$ & 0.30 & 157 & 82 & 31 & & & & \\
\hline $1973 / 74$ & 0.24 & 198 & 165 & 38 & & & & \\
\hline $1974 / 75$ & 0.27 & 167 & 128 & 50 & 2890 & 2564 & 1289 & 875 \\
\hline $1975 / 76$ & 0.33 & 174 & 128 & 28 & 2900 & 2862 & 1536 & 597 \\
\hline $1976 / 77$ & 0.25 & 148 & 123 & 32 & 2821 & 2738 & 1453 & 736 \\
\hline $1977 / 78$ & 0.23 & 139 & 141 & 24 & 2959 & 2809 & 1405 & 854 \\
\hline $1978 / 79$ & 0.22 & 186 & 141 & 48 & 2769 & 2647 & 1688 & 1026 \\
\hline $1979 / 80$ & 0.28 & 141 & 126 & 37 & & & & \\
\hline $1980 / 81$ & 0.21 & 141 & 150 & 57 & & & 1457 & 779 \\
\hline $1981 / 82$ & 0.15 & 123 & 100 & 1 & & & 1538 & 789 \\
\hline $1982 / 83$ & 0.23 & 165 & 106 & 55 & & & 1412 & \\
\hline $1983 / 84$ & 0.27 & 176 & 146 & 79 & 2748 & & 1524 & \\
\hline $1984 / 85$ & 0.31 & 202 & 118 & 38 & 2788 & & 1544 & \\
\hline $1985 / 86$ & 0.35 & 184 & 137 & 32 & 2802 & 2720 & 1525 & 1002 \\
\hline $1986 / 87$ & 0.33 & 124 & 115 & 4 & 2790 & 2480 & 1529 & 1002 \\
\hline $1987 / 88$ & 0.24 & 143 & 155 & 38 & & & & \\
\hline $1988 / 89$ & 0.17 & 146 & 103 & 47 & 2659 & 2650 & 1455 & 845 \\
\hline $1989 / 90$ & 0.29 & 161 & 127 & 158 & 2725 & 2633 & 1202 & 930 \\
\hline $1990 / 91$ & 0.37 & 121 & 159 & 19 & 2582 & 2614 & 1406 & 829 \\
\hline $1991 / 92$ & 0.24 & 149 & 111 & 81 & 2522 & 2527 & 1568 & 844 \\
\hline $1992 / 93$ & 0.25 & 179 & 154 & 25 & 2549 & 2678 & 1964 & 771 \\
\hline $1993 / 94$ & 0.50 & 120 & 80 & 11 & 2715 & 2538 & 983 & 835 \\
\hline $1994 / 95$ & 0.11 & 156 & 147 & 56 & 2596 & 2535 & 1479 & 956 \\
\hline $1995 / 96$ & 0.47 & 119 & 110 & 52 & & & & \\
\hline $1996 / 97$ & 0.18 & 144 & 127 & 41 & & & & \\
\hline Mean value & 0.26 & 156 & 127 & 45 & 2738 & 2643 & 1471 & 854 \\
\hline
\end{tabular}

radiation balances. The results are presented in Table 3.

As radiation mainly affects net balance through melting, the analysis was conducted on both net and summer balance series. With 14 years of data only, a confidence level of $\mathrm{p}<0.4$ or $\mathrm{p}<0.9$ indicates some limitations to the findings. Introducing radiation components did not consistently improve the correlation coefficient between the net balance and climatic parameters (only from $\mathrm{R}=0.78$ to $\mathrm{R}=0.81$ ). But the correlations between summer balance and summer temperature $-\mathrm{R}=0.68$ and $\mathrm{R}=0.69$ for the Brøggerbreen and Lovénbreen, respectively - rise to $R=0.79$ and $\mathrm{R}=0.75$ when introducing the sum of the global and the long-wave radiation received in July and August.

\section{Discussion and conclusion}

The proposed link between net balance, winter precipitation and summer temperature, as discussed previously by Lefauconnier \& Hagen (1990), remains valid. There is no significant correlation between net balance and radiation. Nevertheless, there is a noticeable increase in the correlation coefficient when introducing the sum of the global and long-wave radiation in July and August, so the usefulness of a radiation component in empirical balance models cannot be excluded.

Radiation values are highly variable during summer, and the efficiency of global radiation is directly linked to albedo, which itself varies through time. Moreover high peaks of global 
Table 3. Correlation coefficients between net or summer balances and climatic parameters. PDD = temperature in positive degreedays; precipitation is in $\mathrm{m}$ water equivalent; $\mathrm{LW}=$ long-wave radiation; $\mathrm{SW}=$ global radiation in $10^{-2} \mathrm{MJ} \mathrm{m}^{-2}$.

\begin{tabular}{|c|c|c|c|c|c|c|}
\hline \multirow[b]{2}{*}{ Glacier } & \multirow{2}{*}{$\begin{array}{l}\text { Number } \\
\text { of years }\end{array}$} & \multirow{2}{*}{$\begin{array}{l}\text { Dependent } \\
\text { variable }\end{array}$} & \multicolumn{3}{|c|}{ Correlation coefficients: } & \multirow{2}{*}{$\begin{array}{l}\text { Explanatory } \\
\text { variables }\end{array}$} \\
\hline & & & Multiple & Partial & Total & \\
\hline (1) M. Lovén & 28 & bn & 0.81 & $\begin{array}{r}0.47 \\
-0.73\end{array}$ & $\begin{array}{r}0.51 \\
-0.69\end{array}$ & $\begin{array}{l}\text { Precipitation Oct-May } \\
\text { PDD July-Oct }\end{array}$ \\
\hline (2) M. Lovén & 28 & bs & 0.85 & $\begin{array}{l}-0.27 \\
-0.74 \\
-0.57 \\
-0.27\end{array}$ & $\begin{array}{r}0.11 \\
-0.75 \\
-0.63 \\
-0.33\end{array}$ & $\begin{array}{l}\text { Precipitation Oct-May } \\
\text { PDD in July } \\
\text { PDD in August } \\
\text { PDD Sept-Oct }\end{array}$ \\
\hline (3) M. Lovén & 14 & bn & 0.78 & $\begin{array}{r}0.44 \\
-0.50\end{array}$ & $\begin{array}{r}0.64 \\
-0.67\end{array}$ & $\begin{array}{l}\text { Precipitation Oct-May } \\
\text { PDD July-Oct }\end{array}$ \\
\hline (4) M. Lovén & 14 & bn & 0.81 & $\begin{array}{r}0.49 \\
-0.61 \\
-0.33\end{array}$ & $\begin{array}{r}0.64 \\
-0.69 \\
-0.45\end{array}$ & $\begin{array}{l}\text { Precipitation Oct-May } \\
\text { PDD July-Oct } \\
\text { LW plus SW in July and Aug }\end{array}$ \\
\hline (5) M. Lovén & 14 & bs & 0.75 & $\begin{array}{l}-0.64 \\
-0.28\end{array}$ & $\begin{array}{l}0.69 \\
0.40\end{array}$ & $\begin{array}{l}\text { PDD July-Oct } \\
\text { LW plus SW in July and Aug }\end{array}$ \\
\hline (6) A. Brøgger & 14 & bs & 0.77 & $\begin{array}{l}-0.68 \\
-0.47\end{array}$ & $\begin{array}{l}-0.68 \\
-0.47\end{array}$ & $\begin{array}{l}\text { PDD July-Oct } \\
\text { LW plus SW in July and Aug }\end{array}$ \\
\hline
\end{tabular}

radiation are associated with low peaks of longwave radiation. Therefore, monthly data are not the best to analyse the possible influence of the radiation - daily or even hourly data are preferable. If possible, an index of the albedo values must be introduced as well.

The dependence of the short-wave and longwave radiation balance on the cloudiness has been described by Ambach (1974). The influence of weather conditions on the state of the surface and on the resulting change in albedo has also been noted (e.g. Schytt 1949; Ambach 1960; Muller \& Keeler 1969). Based on the change in reflectance values in the three SPOT bands measured with a field radiometer over the two studied glaciers, this influence has been also discussed by Lefauconnier, Lybéris \& Parrot (1991) and Parrot et al. (1993). The dynamic scale of the reflectance from snow to dusty blue-ice is enlarged after overcast conditions, mainly due to the very low values for the blue-ice and dusty blue-ice with a glazed and wet surface. The scale is reduced with clear sky conditions due to the formation of the "weathering crust" followed by increasing reflection and scattering.

With cloud cover, the increase in long-wave radiation leads to the destruction of the weathering crust and a lower albedo. When a clear sky follows, high values of global radiation will have their greatest effect on surfaces with temporarily low albedos; the formation of the weathering crust will result in a higher albedo and a decreasing efficiency of the global radiation. High global radiation values can be considered as introducing a negative feedback on its own efficiency. The frequency of the change between clear sky and cloud cover, associated with a change in the balance between long-wave and global radiation, introduces an important variation in the efficiency of global radiation. Future work on glacier mass balance reconstruction and modelling will should build up an index taking into account these factors.

\section{References}

Ambach, W. 1960: Investigation of the heat balance in the area of ablation on the Greenland ice cap. Arch. Meteorolog., Geophys. Bioclimat. Ser, B 10(3), 281-288.

Ambach, W. 1974: The influence of cloudiness on the net radiation balance of a snow surface with high albedo. $J$. Glaciol. 13(67), 73-84.

Björnsson, H., Gjessing, I., Hamran, S.-E., Hagen, J. O., Liestøl, O., Pálsson F. \& Erlingsson B. 1996: The thermal regime of sub-polar glaciers mapped by multi-frequency radio-echo sounding. J. Glaciol. 42(140), 23-32.

Hagen, J. O. \& Liestøl, O. 1990: Long term glacier mass balance investigation in Svalbard, 1950-88. Ann. Glaciol. 14, 101-106.

Hagen, J. O., Liestøl, O., Roland, E. \& Jørgensen, T. 1993: Glacier atlas of Svalbard and Jan Mayen. Nor. Polarinst. Medd. 129. 141 pp.

Hagen, J. O. \& Sætrang, A. 1991: Radio-echo sounding of subpolar glaciers with low-frequency radar. Polar Res. 9(I), 99-107.

Hamberg, A. 1895: En resa till norra Ishavet sommaren 1892. (A voyage north to the Arctic Ocean in summer 1892.) Ymer 14. 
Hisdal, V. \& Finnekåsa, Ø. 1996: Radiation measurements in Ny-Ålesund, Spitsbergen 1988-1992. Nor. Polarinst. Medd. 142. $86 \mathrm{pp}$.

Hisdal, V., Finnekåsa, Ø. \& Vinje, T. 1992: Radiation measurements in Ny-Alesund, Spitsbergen 1981-1987. Nor. Polarinst. Medd. $118.380 \mathrm{pp}$.

Lefauconnier, B. \& Hagen, J. O. 1990: Glaciers and climate in Svalbard, statistical analysis and reconstruction of the Brogger glacier mass balance for the last 77 years. Ann. Glaciol. 14, 148-152.

Lefauconnier, B. \& Hagen, J. O. 1991: Surging and calving glaciers in eastern Svalbard. Nor. Polarinst. Medd. 116. 130 $\mathrm{pp}$.

Lefauconnier, B., Hagen, J. O., Pinglot, F. \& Pourchet, M. 1994: Mass-balance estimates on the glacier complex Kongsvegen and Sveabreen, Spitsbergen, Svalbard, using radioactive layers. J. Glaciol. 40(135), 368-376.

Lefauconnier B., Lybéris, N. \& Parrot J. F. 1991: Analyse de l'état de surface de deux glaciers sub-polaires à l'aide des données SPOT et d'un modèle numérique de terrain. (Analysis of the state of surface of two sub-polar glaciers by combining SPOT data and a DTM.) Proceedings of the 5 th International Colloquium: Physical Measurements and Signatures in Remote Sensing. Courchevel, France, 14-18 January 1991. European Space Agency Special Publication $319,639-642$.

Martin, S. 1977: Analyse et reconstruction de la série des bilans annuels du glacier de Sarennes, sa relation avec les fluctuations du niveau de trois glaciers du massif du Mont-
Blanc (Bossons, Argentières, mer de glace). (Analysis and reconstruction of the annual mass balance series of the Sarennes glacier, its relation with the fluctuation of three glaciers on the massif of Mont Blanc.) Z. Gletsch.kd. Glazialgeol. 13(1/2), 127-153.

Melvold, K. \& Hagen, J. O. 1998: Evolution of a surge-type glacier in its quiescent state: Kongsvegen, Spitsbergen, 1964-1995. J. Glaciol. 44(147), 394-404.

Müller, F. \& Keeler, C. M. 1969: Errors in short term ablation measurements on melting ice surfaces. J. Glaciol. $8(52)$, 91-104.

Parrot, J. F., Lybéris, N., Lefauconnier, B. \& Manby, G. 1993; SPOT multispectral data and digital terrain model for the analysis of ice-snow field on Arctic glaciers. Int. J. Remote Sens. 14(3), 425-440.

Schytt, W. 1949: Re-freezing of melt-water on the surface of glacier ice. Geogr. Ann, 31(1/4), 222-227.

Vijne, T. 1976: Radiation conditions in Spitsbergen in 1974. Nor. Polarinst. Arbok 1974, 205-209.

Vijne, T. 1977a: Radiation conditions in Spitsbergen in 1975. Nor. Polarinst. Årbok 1975, 175-178.

Vijne, T. 1977b: Radiation conditions in Spitsbergen in 1976. Nor. Polarinst. Arbok 1976, 317-318.

Vijne, T. 1978: Radiation conditions in Spitsbergen in 1977. Nor. Polarinst. Årbok 1977, 293-295.

Vijne. T. 1979: Radiation conditions in Spitsbergen in 1978. Nor. Polarinst. Årbok 1978, 67-68.

Vijne, T. 1980: Radiation conditions in Spitsbergen in 1979. Nor. Polarinst. Årbok 1979, 57-58. 